SULUH Jurnal Bimbingan Konseling, April 2017, Volume 3 Nomor 2 (32-35)

http://jurnal.umpalangkaraya.ac.id/ejurnal/suluh

\title{
ANALISIS SIKAP APATIS PESERTA DIDIK KELAS XI SAR-1 DI SMK NEGERI 2 PALANGKA RAYA
}

\author{
Oleh \\ Krisnila, Andi Riswandi BP
}

\begin{abstract}
ABSTRAK
Penelitian ini bertujuan untuk memperoleh informasi mengenai sikap apatis peserta didik si kelas XI SAR-1 SMK Negeri 2 Palangka Raya. Subjek dalam penelitian ini adalah kepala sekolah, guru bimbingan dan konseling, guru mata pelajaran, dan 4 peserta didik SMK Negeri 2 Palangka Raya. Penentuan subjek penelitian dengan teknik purposive sampling. Teknik pengumpuan data yang digunakan adalah observasi, wawancara dan dokumentasi. Metode yang digunakan adalah studi kasus. Teknik analisis data menggunakan analisis data kualitatif.

Hasil penelitian menunjukkan bahwa sikap apatis peserta didik di kelas XI SAR-1 SMK Negeri 2 Palangka Raya terlihat pada saat pembelajaran berlangsung dalam bentuk tidak berani berpendapat, tidak berani mengutarakan jawaban, tidak mau dan tidak berani maju ke depan kelas, merasa tidak mampu melakukan sesuatu, takut gagal, tidak mau bekerja sama, tidak peduli dengan pertanyaan teman dan guru maupun lingkungan disekitarnya
\end{abstract}

\section{Kata Kunci: Sikap Apatis}

(C) Universitas Muhammadiyah Palangkaraya

\section{PENDAHULUAN}

Bangsa Indonesia sebagai salah satu negara berkembang yang tidak akan maju sebelum memperbaiki kualitas sumber daya manusianya. Kualitas hidup suatu masyarakat akan meningkat jika ditunjang dengan pendidikan yang baik. Dengan sistem pendidikan yang baik memungkinkan perubahan yang signifikan dalam cara serta pola pikir masyarakat Indonesia itu sendiri. Namun, realita yang adadi masyarakat kita masih menganut cara berfikir tradisional, yaitu manusia yang lebih mementingkan kepentingan pribadinya sendiri tanpa memperdulikan situasi dan kondisi disekitarnya. Hal ini akan berdampakburuk diantara hubungan sesama individu. Sikap ketidakpedulian terhadap permasalahanpermasalahan lingkungan disebut juga dengan sikap apatis.

Bruno dalam (Syah, 2013: 123), sikap (attitude) adalah kecenderungan yang relatif menetap untuk bereaksi dengan cara baik atau buruk terhadap orang atau barang tertentu. Dalam hal ini, perwujudan perilaku belajar siswa akan ditandai dengan munculnya kecenderungan-kecenderungan baru yang telah berubah terhadap suatu objek, tata nilai, peristiwa dan 
sebagainya. Heymans dalam (Kartono, 2005: 35-40) membagi tipe-tipe manusia menjadi delapan yang salah satunya adalah apatis (apathis). Apatis berasal dari kata apatheia, yaitu dari $a$ yang berarti tanpa dan pathos atau pathe berarti perasaan, jadi apatis adalah tanpa perasaan, acuh tak acuh. Sejalan dengan pemikiran tersebut, Alwisol (2009: 63) menyatakan bahwa dalam istilah psikologi, apatis merupakan keadaan ketidakpedulian, dimana seseorang individu tidak menanggapi rangsangan kehidupan emosional, sosial atau fisik.

Heymans (dalam Kartono, 2005: 40), seorang yang memiliki sikap apatis memiliki aktivitas yang lamban, menyukai cara yang mudah, suka berfikir panjang, memiliki kebiasaan malas, dan cenderung tidak suka berbuat sesuatu, sosiabilitas lemah, sukar berdamai, afeksinya konstan, suka menarik diri, acuh tak acuh terhadap pendapat orang lain, kaku, beku, berpegang secara mati-matian pada kesenangannya, bersikap tertutup, suka menyendiri, dan seorang individu yang sangat menjemukan. Sementara itu, Alwisol (2009: 63) menyatakan bahwa ciri-ciri seseorang bersikap apatis adalah sebagai berikut: (a) Menifestasi kepribadian otoriter, (b) putus asa, (c) tidak percaya, dan (d) tidak berdaya menarik diri dari kegiatan

Fenomena dilapangan menunjukan bahwa ada siswa yang bersikap apatis selama proses pembelajaran berlangsung. Peserta didik tersebut tidak memperdulikan apa yang ditanyakan oleh gurunya. Ketika mempunyai jawaban pada saat guru bertanya, dia ragu dan tidak percaya diri dengan jawaban yang dia miliki. Peserta didik tersebut sering menyendiri dan tidak mau bergaul dengan temantemannya, bahkan ketika temannya bertanya peserta didik itu hanya diam. Hal ini sesuai dengan ciri-ciri sikap apatis yaitu menutup jalan untuk berkomunikasi, tidak menghiraukan orang lain, ragu dalam bertindak, ragu pada saat mengutarakan jawabannyadan tidak percaya diri.

Sikap apatis yang dialami peserta didik seperti ini tidak bisa dibiarkan karena akan menghambat peserta didik untuk memperoleh ilmu pengetahuan, sehingga peserta didik akan gagal naik kelas, tidak bisa menjawab pertanyaan yang diberikan ketika guru bertanya, dan sulit dalam bergaul dengan temannya. Untuk mengatasi sikap apatis yang dialami peserta didik ini bukan hanya tugas guru bimbingan dan konseling saja, melainkan menjadi tugas kepala sekolah, guru mata pelajaran, wali kelas serta orang tua peserta didik. Hal inilah yang menjadi alasan bagi peneliti untuk dilakukannya penelitian dengan judul Analisis Sikap Apatis Peserta Didik Kelas XI SAR-1 di SMK Negeri 2 Palangka Raya.

\section{METODE PENELITIAN}

Menurut Sugiyono (2013: 2) metode penelitian adalah merupakan cara ilmiah untuk mendapatkan data dengan tujuan dan kegunaan tertentu. Dalam penelitian ini, pendekatan yang digunaan adalah pendekatan penelitian kualitatif. Margono (2010:36) penelitian kualitatif memerlukan ketajaman analisis, objektivitas, sistematik, dan sistemik sehingga diperoleh ketepatan 
dalam interpretasi, sebab hakikat dari suatu fenomena atau gejala penganut penelitian kualitatif adalah totalitas. Sementara itu, Kirk dan Miller (dalam Maleong, 2006: 4) mendefinisikan penelitian kualitatif adalah tradisi tertentu dalam ilmu pengetahuan sosial yang secara fundamental bergantung dari pengamatan pada manusia baik dalam kawasannya maupun dalam peristilahannya.

Jenis penelitian dalam penelitian ini yaitu menggunakan penelitian studi kasus (Case Study). Walgito (2010: 92) studi kasus (case study) merupakan suatu metode untuk menyelidiki atau mempelajari suatu kejadian mengenai perseorangan atau kelompok. Winkel dan Hastuti (2006: 311) menyatakan bahwa studi kasus dalam rangka pelayanan bimbingan merupakan metode untuk mempelajari keadaan dan perkembangan siswa secara lengkap dan mendalam, dengan tujuan memahami individualitas siswa dengan baik dan membantunya dalam perkembangan selanjutnya, sedangkan menurut Rahardjo\&Gudnanto (2011:250), studi kasus adalah suatu metode untuk memahami individu yang dilakukan secara integrative dan komprehensif agar diperoleh pemahaman yang mendalam tentang individu tersebut beserta masalah yang dihadapinya dengan tujuan masalahnya dapat terselesaikan dan memperoleh perkembangan diri yang baik.

Subjek penelitian ini yaitu kepala sekolah, guru BK, walikelas, guru kelas dan peserta didik. Alat pengumpul data dalam penelitian in yaitu angket, wawancara, observasi, dokumentasi.

\section{HASIL DAN PEMBAHASAN}

a. Analisis

Data mengenai sikap apatis peserta didik diperoleh dari observasi terhadap proses pembelajaran selama 3 kali. Berdasarkan hasil observasi tersebut diperoleh empat (4) peserta didik yaitu peserta didik AR, IM, FT dan RD yang memiliki sikap apatis selama proses pembelajaran. Bentuk apatis yang dimunculkan diantaranya yaitu (a) saya bukan tipikal orang yang suka berpendapat, (b) takut salah dan ragu-ragu dalam menjawab, (c) takut diejek dan diolok-olok karena jawaban itu salah, (d) kurangnya percaya diri, (e) kalau saya salah pasti diolokin teman, (f) beberapa orang yang susah diatur untuk diajak bekerja sama dan hanya menerima beres saja

b. Pembahasan

Hasil observasi kepada subjek penelitian menunjukkan bahwa adanya sikap apatis peserta didik di kelas XI SAR-1 SMK Negeri 2 Palangka Raya. Berdasarkan hasil penelitian, sikap apatis yang ada pada diri siswa yaitu sikap dimana pada saat pembelajaran berlangsung peserta didik tersebut tidak berani berpendapat, tidak berani mengutarakan jawaban, tidak mau dan tidak berani maju ke depan kelas, merasa tidak mampu melakukan sesuatu, takut gagal, tidak mau bekerja sama, tidak peduli dengan pertanyaan teman dan guru maupun 
lingkungan disekitarnya. Hal tersebut sejalan dengan pendapat Alwisol (2009: 63) yang mendefiniskan apatis sebagai suatu keadaan ketidakpedulian, dimana seorang individu tidak menanggapi rangsangan kehidupan emosional, sosial atau fisik.

\section{KESIMPULAN}

Berdasarkan hasil penelitian dan pembahasan yang telah dilaksanakan studi mengenai sikap apatis peserta didik kelas XI SAR-1 di SMK Negeri 2 Palangka Raya Tahun Pelajaran 2015/2016, maka dapat disimpulkan bahwa sikap apatis peserta didik di kelas XI SAR-1 SMK Negeri 2 Palangka Raya terlihat pada saat pembelajaran berlangsung dalam bentuk tidak berani berpendapat, tidak berani mengutarakan jawaban, tidak mau dan tidak berani maju ke depan kelas, merasa tidak mampu melakukan sesuatu, takut gagal, tidak mau bekerja sama, tidak peduli dengan pertanyaan teman dan guru maupun lingkungan disekitarnya.

\section{DAFTAR PUSTAKA}

Alwisol. 2009. Psikologi Kepribadian Edisi Revisi. Malang: UMM Press

Arikunto, Suharsimi. 2006. DasarDasar Evaluasi Pendidikan. Jakarta: PT Bumi Aksara

Kartono, Kartini. 2005. Teori Kepribadian. Bandung: Mandar Maja
Maleong, Lexy J. 2006. Metodologi Penelitian Kualitatif. Bandung: PT. Remaja Rosdakarya

Margono, S. 2010. Metodologi Penelitian Pendidikan:

Komponen MKDK. Jakarta: Rinneka Cipta

Rahardjo, Susilo \& Gudnanto. 2011. Pemahaman Individu Teknik Non Tes. Kudus: Nora Media Enterprise

Sutopo, HB. 2006. Metode Penelitian Kualitatif. Surakarta: UNS Press

Sugiyono. 2008. Metode Penelitian Kuantitatif, Kualitatif, dan $R \& D$. Bandung: Alfabeta

Sugiyono. 2013. Metode Penelitian Kuantitatif, Kualitatif, dan $R \& D$. Bandung: Alfabeta

Syah, Muhibbin. 2013. Psikologi Belajar. Jakarta: PT RajaGrafindo Persada

Umar, Husein. 2003. Metode Penelitian untuk Skripsi dan Tesis Bisnis. Jakarta: PT RajaGrafindo Persada

Walgito, Bimo. 2010. Bimbingan dan Konseling (Studi \& Karir). Yogyakarta: ANDI

Winkel, W. S dan Hastuti. 2006. Bimbingan dan Konseling di Institusi Pendidikan. Yogyakarta : Media Abadi 